\title{
Cost-benefit analysis of living wall systems on school building skins in a hot climate
}

\author{
M. Haggag \& A. Hassan \\ UAE University, United Arab Emirates
}

\begin{abstract}
This study is based on a local green school initiative that takes place at an international school in the city of $\mathrm{Al}$ Ain, in the Emirate of Abu Dhabi. Despite the valuable advantages of the use of living wall systems (LWSs) pointed out by authors in previous research, there is little experience of using this technique, and the additional costs associated with a vegetated living wall installed on a building façade generally concern developers. To get a clear picture of the real financial incentives of using living wall strategies as a high-energy efficient skin, this study investigates a cost-benefit analysis (CBA) of the installed LWS, taking into consideration the energy saving and environmental impact of the building skins. The actual installation and running costs of the LWSs are mainly compared with the reduction of cooling loads and increased value of the property, while the related environmental benefits are ignored at this stage.

Keywords: cost-benefit analysis, energy performance, living wall, environmental impact.
\end{abstract}

\section{Introduction}

During the last few decades, energy-efficient design of school buildings has been a global concern. Nearly 25\% of energy consumption in schools could be reduced through a better building design and using energy-efficient technologies combined with improvements in operations and maintenance [1]. Buildings consume approximately $40 \%$ of the total energy consumption. As shown in figure 1, most of this energy consumption is devoted for the provision of HVAC (67\%) and lighting (14\%) [2]. Literature concerned with energy performance of school buildings is devoted to energy savings through specific features such as a utilization of solar energy and construction features that include thermal 
insulation, thermal mass, shading, HVAC performance, and geothermal [3-5]. However, basic assumptions regarding thermal comfort, indoor air quality, occupancy, internal loads, and architectural features of the school building are not identical and usually based on local preferences

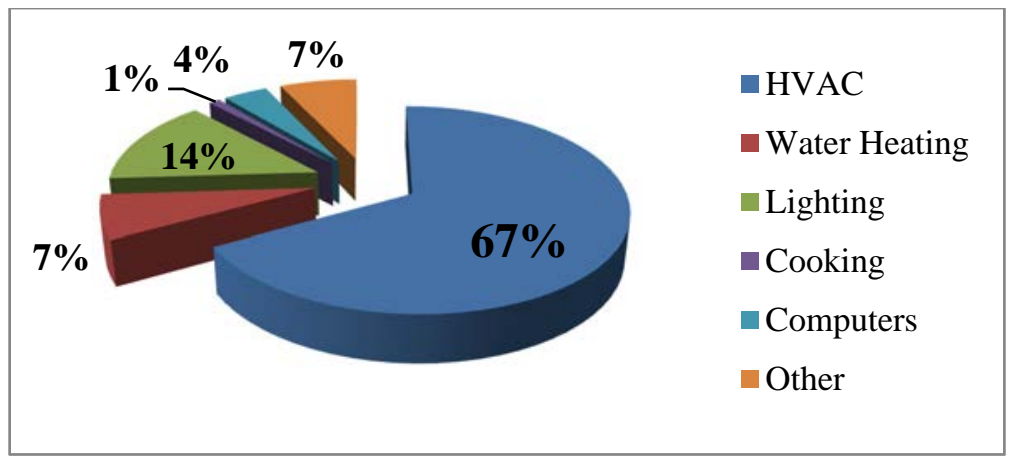

Figure 1: Energy consumption in school buildings [2].

Sustainable school benchmarks have been developing worldwide in attempts to meet energy-efficient design of school buildings. These benchmarks include the Leadership in Energy and Environmental Design (LEED) for school buildings by the US Green Building Council [5], Energy Smart School Program by the US Environmental Protection Agency [6], the Benchmarking Guide for School Facility Managers by the Natural Resources Canada's Office of Energy Efficiency [7], and the UK Practice Guide for primary schools [6].

In 2009, Estidama Pearl Rating System for school buildings emerged as a local effort in the UAE following the Estidama sustainability initiative which was introduced by Abu Dhabi Urban Planning Council [8]. The Pearl Building Rating System (PBRS) promotes the development of sustainable buildings by reducing the use of natural resources, improving quality of life and reducing adverse impact on the environment, and encouraging water and energy saving [8]. The focus of this study, as part of an on-going research project, is the assessment of the occupied school building after installation of a vegetated wall application on the building facades.

Previous researchers have identified different methods for Building Performance assessment: Computational approaches relying on input collected data by an energy auditor; performance approaches based on energy bills; and Measurement based approaches consisting of in-situ measurement procedures [9]. In this study, critical role of building skin in the overall building performance is emphasized and the external wall performance is evaluated as an energy efficient design parameter in the school buildings. Building skins play an important role on the overall energy performance by controlling heat transfer and solar radiation. A natural passive cooling system is an option for sustaining building skins and reducing air conditioning costs. To minimize the effect of radiant energy, a reflective waterproof coating and installation barriers are essential. This can 
reduce heat gains by about 25\% [10]. Green walls can also reduce heat gain and their surface temperature. Previous studies have shown that the external surface of a green wall is up to $10^{\circ} \mathrm{C}$ cooler than an exposed wall; therefore the U-value for the green wall is usually lower and helps to reduce cooling loads [11].

\section{Green wall systems}

Green wall is used as a term for both Living Walls and Green Façades. Living Walls are self-sufficient vertical gardens composed of pre-vegetated panels, vertical modules or planted blankets [12]. These panels, which are usually made of plastic, support a diversity and density of plant species. As shown in figure 2, the popular LWSs are: Modular Living Walls; Vegetated Mat walls; and Landscape walls [13-15]. Modular living wall system consists of standard units that hold growing media and plants. Vegetated mat wall system has two layers of synthetic fabric which support plants and growing media. Landscape walls are constructed from stacking material with room for growing media and plants. Green façades are made up of climbing plants that growing directly on a wall or supporting structure. The plant grows up the wall while being rooted to the ground, in intermediate planters or on the rooftops. Rigid panels and cable systems can be used to hold vines off the wall surface.

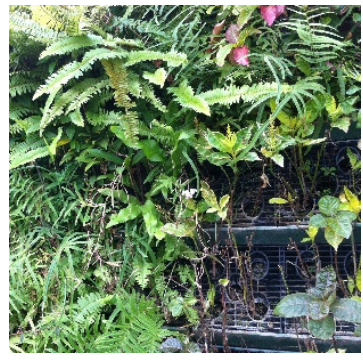

Modular living wall system

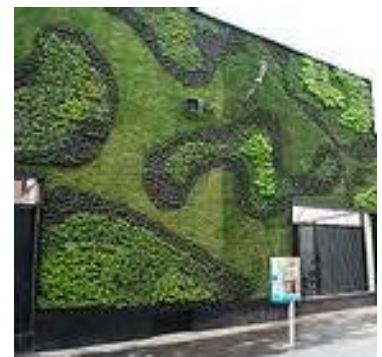

Vegetated mat wall system [16]

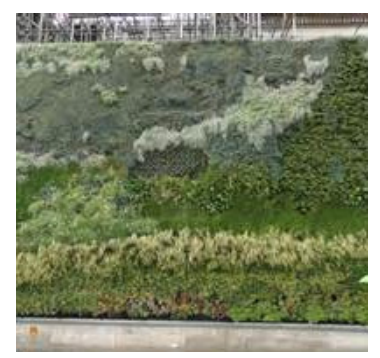

Landscape wall system [17]

Figure 2: Living wall systems.

A number of studies have been conducted to explore the thermal effect of vegetation on building skins. In their study, Wong et al argued that vertical greenery systems can reduce air conditioning load by shading walls and windows from incoming solar energy resulting in a $5.5^{\circ} \mathrm{C}$ reduction in the outdoor ambient temperature wherein shading effect was found to reduce cooling load by about $23 \%$ and the usage of fans by $20 \%$ resulting in an $8 \%$ reduction in annual energy consumption [18]. Through simulation, a 100\% greenery coverage with plants of higher shading coefficient, proved to achieve a 17.93\% drop in cooling load [18]. Also the study highlights that a lower shading coefficient results in better greenery effectiveness on glass facades. Given that the thermal transfer value of the building skin and the leaves coverage of a plant are useful design variables when it comes to achieving the intended amount of thermal load reduction [19, 20]. In addition 
to their significant thermal benefits, plants and trees have been used as barriers against noise pollution. Green walls have a better acoustical insulation than that of bare wall. It can reach up to $30 \mathrm{db}$, depending mainly on factors that influence noise reductions including depth of the growing media, type of plants, materials used for the structural components of the living wall system, and the layer of air between the plants and the wall [21].

\section{Experimental procedure}

Liwa International School (LIS) was selected as a case study to explore the performance of the living wall in the hot climate. The school is located in the hot climate of Al-Ain City, UAE (in the south west of the city at latitude $24^{\circ} 16^{\prime}$ and longitude $55^{\circ} 36^{\prime} \mathrm{E}$ ). The daytime temperatures range from 25 to $35^{\circ} \mathrm{C}$ in winter, and can reach as high as $50^{\circ} \mathrm{C}$ in summer. The relative humidity typically ranges from $13 \%$ (very dry) to $88 \%$ (very humid) over the course of the year [22].

A vegetated living wall was installed on the school building façades, using living wall planter units made of plastic boxes (30 x $30 \times 25 \mathrm{~cm})$, fixed on the façades with drip irrigation pipes $(13 \mathrm{~mm})$ and a variation of plant species (figure 3). Two identical class rooms (width: $5 \mathrm{~m}$; length: $7 \mathrm{~m}$; and height: $3.5 \mathrm{~m}$ ) facing East have been tested: one with external bare walls and the other with living green walls. Both are facing the eastern direction and constructed from hollow concrete blocks (20 cm thickness) covered by white Stucco plaster with a heat absorption value of 0.6 [23]. To determine the impact of thermal performance of the green wall on indoor and outdoor spaces, temperatures at four locations were recorded for both bare and green walls. These locations include ambient air temperature (1m away from the external wall); external surface temperature; internal surface temperature; and internal air temperature (1 m away from the internal wall). Based on the historical weather data of Al-Ain city, the experiments were conducted 1st July to 1st August which guarantees the highest ambient temperature and solar radiation intensity. From the measured temperature data, the cooling load for the bare and green wall were calculated and compared to determine the effect of green wall on cooling load reduction of the selected spaces.

\section{Experimental and simulation results}

The solar radiation incident on the bare wall directly started heating the external wall surface while in case of the green wall the radiation was partially blocked by the vegetation which produced shading on the wall surface. The experiments result shows that the external surface temperature on bare wall stayed around $54^{\circ} \mathrm{C}$ while the temperature on the green wall remained at an average of $48^{\circ} \mathrm{C}$. A similar trend was observed for the rest of the duration of experiment with slight variation in the magnitude of the temperature regulation. The reduced external surface temperature on green wall yields a reduced internal surface temperature compared to bare wall. The internal surface temperature on the bare wall stays at an average of $52^{\circ} \mathrm{C}$ while the internal surface temperature on the green wall stays at $46^{\circ} \mathrm{C}$ 


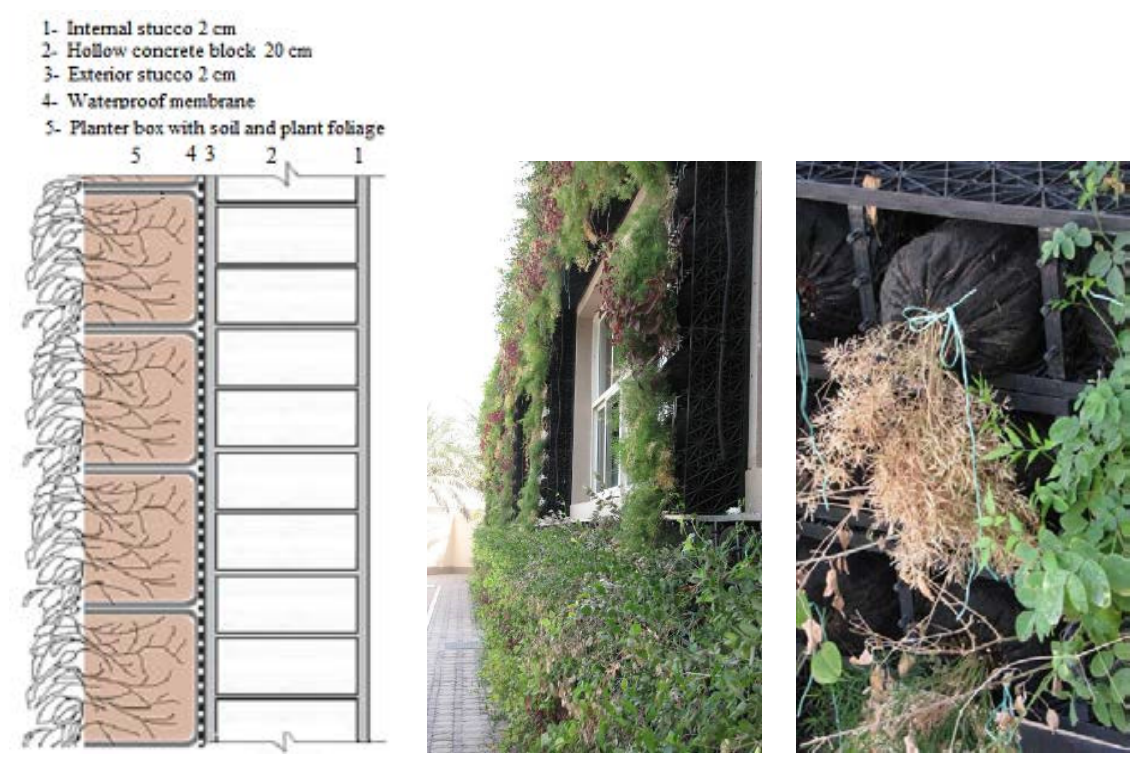

Figure 3: Installed living wall system, Liwa International School, Al-Ain.

which shows a similar trend and magnitude of temperature regulation as of external wall. Since the internal wall is in thermal communication with the indoors air through convection this drop in internal surface temperature yields a drop in indoor ambient temperature with green wall compared to bare wall with an average of $6^{\circ} \mathrm{C}$. The result also shows that the internal surface of the green wall remains cooler than the internal surface of the bare wall during both the peak day time (with a difference of $4-6^{\circ} \mathrm{C}$ ) and the peak night time (with a difference of $1-2.5^{\circ} \mathrm{C}$ ) [23]. It means that the green wall saves more energy during day time than night time by keeping the space from overheating. The reduction in the internal surface temperature and the ambient air temperature of the vertical greenery system is occurred mainly due to: the decreased heat gain caused by green wall; the evaporative cooling caused by the irrigation water; and heat insulation caused by low thermal conductivity of the plant foliage and the soil. The study concludes that the shading effect of vertical greenery system can reduce peak time indoor air temperature by $5-7^{\circ} \mathrm{C}$ for the month of July, and reduce the peak air conditioning energy consumption by about $20 \%$, which is in agreement with previously reported work elsewhere [10, 11, 23].

A simulation model was created in energy simulation programme eQuest taking all the construction details of the tested rooms and experimental result of cooling load in case of bare wall was compared with simulated cooling load of bare wall for the month of July as shown in figure 4 . The results showed an agreement with a variation below $5 \%$ which validates model. The model was then extended to include green wall features as an added R-value calculated from specification of green wall systems. The simulated results of the green wall were 
compared with the experimental results of the green wall for the cooling load and it was observed that the cooling load of simulated green wall was in agreement with the cooling load of experimental green wall for the test duration of month of July.

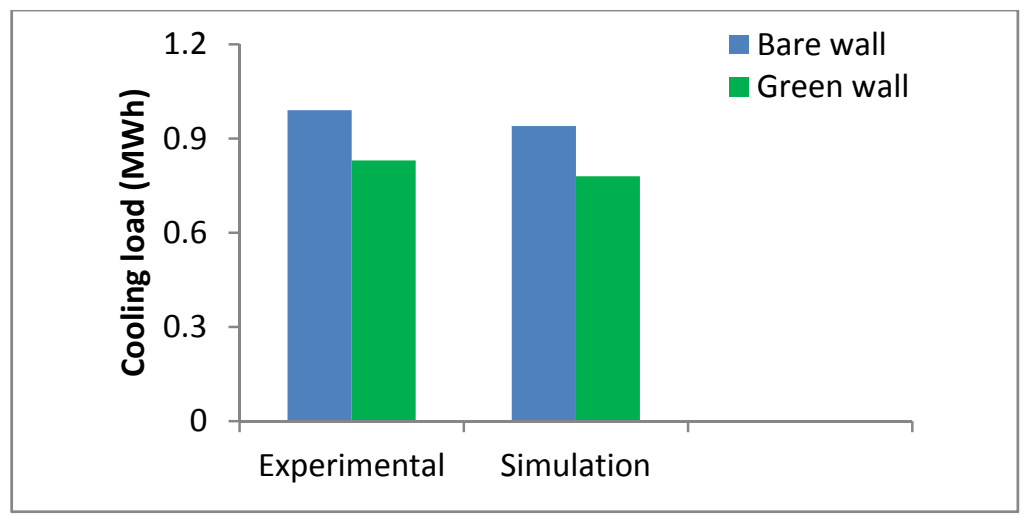

Figure 4: Comparison of experimental and simulation cooling loads for the bare and green system to validate the simulation model.

Based on validated simulation models the cooling load was predicted for the whole year for the bare wall and green wall, to calculate the yearly cooling load reduction achieved by green wall compared to bare wall. The cooling loads of the green and bare wall are presented in figure 5 . The figure shows that the cooling load of the green wall remained consistently lower compared to the bare wall yielding a total yearly cooling load of 4.53 MWh compared to 5.54 MWh of the bare wall hence resulting a drop in cooling load of about $18 \%$.

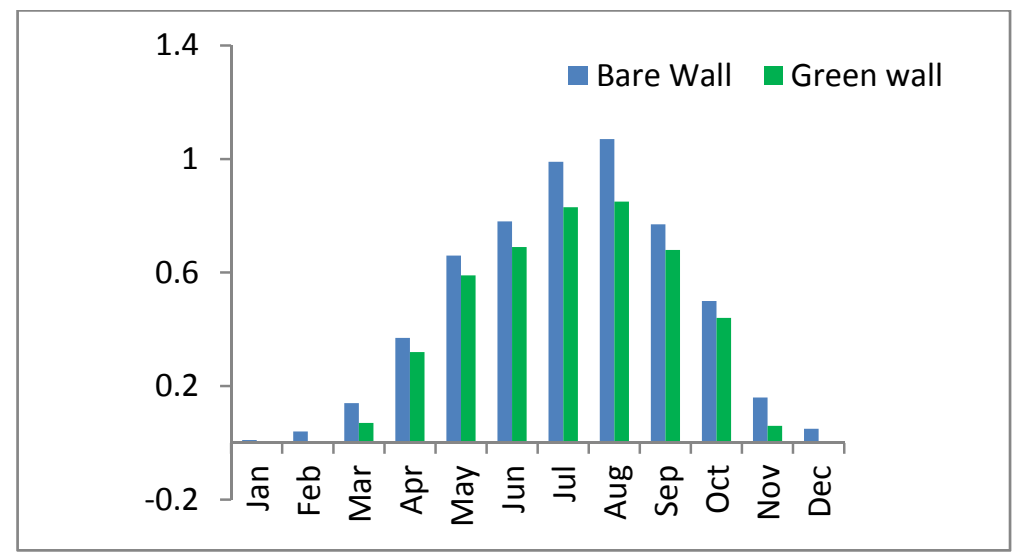

Figure 5: Comprision of yearly cooling load of the experimental bare wall and the green wall installed at Liwa Internationl School predicted through the validated simulation model. 


\section{Cost-benefit analysis of LWS}

It is clear that the use of LWSs improves the environmental condition of urban areas due to its energy saving, extension of building life, $\mathrm{CO} 2$ capture, and noise reduction. However, it is not clear that the vertical greenery systems are economically sustainable. The study presents a Cost-Benefit Analysis (CBA) of the LWS installed on the building skins of LIS building, considering environmental and social benefits as well as life cycle span of the building skin. Installation, maintenance, and running costs of the greenery system are compared with cooling load reduction, air-quality improvement; sound treatment, and other related benefits. The CBA covers the initial cost the greenery system, maintenance cost, and running costs. Economic benefits related to building skins longevity and energy saving for cooling systems are also included in the study. The calculation of some related benefits are based on the literature review.

\subsection{Cost of the LWS}

Plastic planter boxes $30 \times 30 \times 25 \mathrm{~cm}$, including installation cost, plants and growing media: $220 \mathrm{US} \$ / \mathrm{m}^{2}$

Irrigation system cost (PVC pipes): $30 \mathrm{US} \$ \mathrm{~m}^{2}$

Water for irrigation: 0.9 US $\$ / \mathrm{m}^{2} /$ year $\left(6-8 \mathrm{~m}^{3} /\right.$ day)

Cost per unit area $=288 \mathrm{US} \$ / \mathrm{m}^{2}$

The façades area covered by LWS $=10 \mathrm{~m}^{2}$

Total LWS cost for the tested space $=2880$ US\$

\subsection{Benefit of the LWS}

The benefit of the LWS is calculated through the energy savings caused by reduced cooling load and increased rental rate and increased rental rate [24].

Cooling load reduction $=1.01 \mathrm{MWh} /$ year

Average yearly rent for the space $=3266$ US\$

Increased rental rate $=4 \%$

Savings on rental $=0.04 * 2000=80$ US $\$$ year

\section{Scenario 1}

Local unsubsidized cost of electricity $=320 \mathrm{AED} / \mathrm{MWh}=87.12 \mathrm{US} \$$

Energy cost savings $=87.128 * 1.01=88$ US $\$$ year

Savings on rental $=80$ US\$

Total Savings $=168$ US $\$ /$ year

Payback period $=2880 / 168=17$ years

\section{Scenario 2}

International levelised energy cost $=132 \mathrm{US} \$ / / \mathrm{MWh}$ [25]

Energy cost saving $=132 * 1.01=133.32$ US\$/year

Savings on rental $=80$ US $\$$ year

Total savings $=213.32$ US $\$$ year

Payback period $=2880 / 213.32=13$ years 
This shows that the using plastic planter boxes might not be the best economic sustainable option of the green wall, as the insulation costs are high comparing with similar systems using plastic mesh. Pay back periods are quite higher in both the scenarios i.e. 17 years considering unsubsidized local electricity rates while 13 years considering levelised international electricity rates.

\section{Conclusion}

The study finds that installation of LWS on the school facades results in the yearly cooling load saving of $18 \%$ when compared to bare wall. The cost-benefit analysis is based on determining simple payback period considering the capital and operating costs while energy savings and increased rental value are included as benefit while ignoring the environmental benefits and inflation rates at this stage. The cost-benefit analysis of the LWS as it stands shows that the LWSs have a longer payback period of 17 years considering the local unsubsidized electricity rates in UAE and drops down to 13 years considering international levelised electricity cost. It therefore finds that they LWS cannot payback in a reasonable time as it stands however the authors expect to achieve reduced payback period once inflation and environmental impacts are included as subject of future study to make the LWS financially viable

\section{Acknowledgement}

The authors would like to express their appreciations to the College of Engineering at the UAEU for funding this research project.

\section{References}

[1] Perez, Y., \& I. Capeluto, Climatic considerations in school building design in hot-humid climate for reducing energy consumption, Applied Energy, 86, pp. 340-348, 2009.

[2] Energy Information Administration, Millennial Net, 2012, http://ww.millennialnet.com

[3] Becker, R. et al., Improving energy performance of school buildings while ensuring indoor air quality ventilation, Building and Environment, 42, pp. 3261-3276, 2007.

[4] U.S. Environmental Protection Agency (2007); ENERGY STAR ${ }^{\circledR}$ and Other Climate Protection Partnerships 2007 Annual Report, Retrieved, December 2010, http://www.energystar.gov/ia/news/downloads/annual_report_2007.pdf

[5] US Green Building Council (2007); LEED ${ }^{\circledR}$ for Schools for New Construction and Major Renovations, retrieved December 2010, http://www.usgbc.org/ShowFile.aspx?DocumentID=2593

[6] Hernandez, P. et al., Development of energy performance benchmarks and building energy ratings for non-domestic buildings: An example for Irish primary schools, Energy and Buildings, 40, pp. 249-254, 2008. 
[7] Natural Resources Canada, Office of Energy Efficiency (2001); Benchmarking guide for school facility managers, retrieved December 2010, http://oee.nrcan.gc.ca/Publications/commercial/pdf/m92-221-2001E.pdf

[8] Abu Dhabi Urban Planning Council, The Pearl Rating System for Estidama Building Rating System, Design \& Construction (Version 1.0), retrieved December 2010.

[9] Wheeler, S. and T. Beatley, The Sustainable Urban Development, Timothy, New York, 2004.

[10] Reid, E., Understanding Buildings: a Multidisciplinary Approach, Longman, London, 2001.

[11] Wigginton, M. and J. Harris, Intelligent skins. Butterworth, Oxford, 2002.

[12] Caplow, T. et al., Vertically Integrated Greenhouse: Realizing the Ecological Benefits of Urban Food Production, Proceeding of the Eco-city World Summit, San Francesco, USA, 2008.

[13] Kontoleon, J. and E. Eumorfopoulou, The effect of the orientation and proportion of a plant-covered wall layer on the thermal performance of a building zone, Building and Environment 45, pp. 1287-1303, 2010.

[14] Perini, K. et al., Vertical greening systems and the effect on air flow and temperature on the building envelope, Building and Environment 46, pp. 2287-2294, 2011.

[15] Timur, O and E. Karaca, Vertical Gardens, chapter 22, http://dx.doi.org/10.5772/55763

[16] Green wall at the Universidad del Claustro de Sor Juana, http://en.wikipedia.org

[17] http://landscapeandurbanism.blogspot.com

[18] Wong, N. et al., Thermal evaluation of vertical greenery systems for building walls, Building and Environment, 45, pp. 663-672, 2010.

[19] Becker, R. et al., Improving energy performance of school buildings while ensuring indoor air quality ventilation, Building and Environment, 42, pp. 3261-3276, 2007.

[20] Eumorfopoulou, E. and K. Kontoleon, Experimental approach to the contribution of plant-covered walls to the thermal behavior of building envelopes, Building and Environment, 44, pp. 1024-1038, 2009.

[21] http://www.greenroofs.org/index.php/about-green-roofs/green-roofbenefits

[22] Climate: Al Ain, http://en.climate-data.org/location/

[23] Haggag, M. et al., Experimental Study on Reduced Heat Gain through Green Facade in High Heat Load Climate of UAE, International Journal of Energy and Buildings, 82, pp. 668-674, 2014.

[24] Perini, K. and P. Rosasco, Cost-benefit analysis for green façades and living wall systems, Building and Environment 70, pp. 110-121, 2013.

[25] https://www.gov.uk/government/uploads/system/uploads/attachment_data/ file/65713/6883-electricity-generation-costs.pdf 